NASA Technical Memorandum 105644

AIAA-92-3995

\title{
Engine Component Instrumentation Development Facility at NASA Lewis Research Center
}

Robert J. Bruckner and Alvin E. Buggele

National Aeronautics and Space Administration

Lewis Research Center

Cleveland, Ohio

and

Jan Lepicovsky

Sverdrup Technology, Inć.

Lewis Research Center Group

Brook Park, Ohio

Prepared for the

17th Aerospace Ground Testing Conference

sponsored by the American Institute of Aeronautics and Astronautics

Nashville, Tennessee, July 6-8, 1992 


\title{
ENGINE COMPONENT INSTRUMENTATION DEVELOPMENT FACILITY
}

\section{AT NASA LEWIS RESEARCH CENTER}

\author{
Robert J. Bruckner and Alvin E. Buggele \\ National Aeronautics and Space Administration \\ Lewis Research Center \\ Cleveland, Ohio 44135 \\ and \\ Jan Lepicovsky \\ Sverdrup Technology, Inc. \\ Lewis Research Center Group \\ Brook Park, Ohio 44142
}

\begin{abstract}
The Engine Components Instrumentation Development Facility at the NASA Lewis

Research Center is a unique aeronautics facility dedicated to the development of innovative instrumentation for turbine engine component testing. Containing two separate wind tunnels, the facility is capable of simulating many flow conditions found in most turbine engine components. This facility's broad range of capabilities as well as its versatility provides an excellent location for the development of novel testing techniques. These capabilities thus allow a more efficient utilization of larger and more complex engine component test facilities.
\end{abstract}

\section{Introduction}

The need to design and produce more innovative, lighter weight, and highly efficient gas turbine engines has increased the demand for advanced turbine engine component testing. Modern day engine designs, particularly the turbomachinery components, rely heavily on complex computational fluid dynamics (CFD) computer programs. As a result, requirements for more detailed and accurate aerodynamic data have arisen in order to compare and validate these CFD codes with "real world" hardware. New and innovative instrumentation such as laser anemometry and heat flux gauges must continually be developed to increase the state of the art of experimental techniques for the needs of future research. Such novel instrumentation systems and experi- mental techniques often require extensive development, refinement, and calibration. However, to perform these tasks in an engine component test facility quickly becomes prohibitively costly and time consuming. In fact, this is often an impossible task because of unknown flow conditions inside the experimental component. To expedite the development of such systems and techniques, as well as to more efficiently utilize engine component test facilities, NASA Lewis Research Center has designed and constructed a unique facility dedicated to this need. The Engine Component Instrumentation Development Facility contains two wind tunnels designed to simulate the flow conditions (pressure, temperature, and Mach number) found in many engine component tests. It also provides a location for the timely and efficient development of new instrumentation systems and testing techniques, allowing fully functional and mature systems to be utilized in larger, more complex engine component test facilities. This paper discusses the design, capabilities, and versatility of the Engine Component Instrumentation Development Facility.

\section{Facility Description}

\section{Background}

The Engine Component Instrumentation Development Facility is located in test cell SE-1 of the Engine Research Building at NASA Lewis. The facility contains two wind tunnels capable of both subsonic and supersonic operation. The maximum capabilities of both tunnels are listed in 
Table 1. An isometric view of the facility is shown in Fig. 1. Both tunnels contain similar test sections which can house a flowpath up to 6 by 6 in. ( 0.15 by $0.15 \mathrm{~m})$ in cross section and 48 in.

$(1.22 \mathrm{~m})$ in length. Low-pressure exhaust for both tunnels is provided by a central altitude exhaust system which can be maintained at 26 in. of mercury vacuum $(\sim 1.5 \mathrm{psia}, \sim 10 \mathrm{kPa})$. Tunnel 1 uses ambient temperature and pressure inlet air from the test cell. Tunnel 2 is supplied with pressurized inlet air (40 psig, $380 \mathrm{kPa}$ ) from the NASA Lewis central air services. Inlet air to tunnel 2 is filtered, heated, and regulated with the flow conditioning components shown in Fig. 2. Both tunnels are equipped with a particle spray system to seed the flow with known-size particles for laser anemometry studies. An auxiliary air supply and exhaust piping provide both test sections with suction, blowing, and crossflow capabilities. Safety systems incorporated in the design and controls of the facility allow personnel to remain in the test cell during the majority of the operating times. Standard instrumentation (pressure and temperature) is used to control and monitor the conditions in the facility. Current instrumentation under development in this facility includes an open-beam laser fringe anemometry (LFA) system for unsteady supersonic flow studies, a novel heat flux sensor gauge for heat transfer studies, a fiber optic LFA system for turbine testing, and a supersonic calibration duct for LFA particle dynamics studies.

\section{Supply Air System Description}

Inlet air for tunnel 1 is taken directly from the test cell. As such, inlet conditions are limited to ambient temperature and pressure. No inlet flow conditioning is available. Flow rates up to $5 \mathrm{pps}(2.3 \mathrm{~kg} / \mathrm{sec})$ and Mach numbers up to 1.7 can be achieved in this tunnel. An air handler provides adequate make-up air through a central ventilation duct to maintain the test cell at ambient conditions.

Tunnel 2 utilizes the NASA Lewis central air services 40 -psig (380-kPa) supply system. Pressurized air is supplied to the facility through a 4-in.(0.1-m-) diameter carbon steel pipe. The flow conditioning hardware includes a $10-\mu \mathrm{m}$ filter, two $300-\mathrm{kW}$ electric immersion heaters, an electrically actuated ball valve for inlet pressure and flow control, a $1.5-\mu \mathrm{m}$ filter, and a 3 -ft- $(0.93-\mathrm{m}-)$ diameter plenum which houses a flow-spreading cone and straightening screen. Additional heating capacity is provided by electric strip heaters wrapped around the inlet piping and plenum. Inlet temperatures from ambient to $500{ }^{\circ} \mathrm{F}(533 \mathrm{~K})$, pressures up to 55 psia $(380 \mathrm{kPa})$, and Mach numbers from 0 to 3.0 are achievable with this system.

A unique capability of this facility is the auxiliary air supply and exhaust piping system. Both ambient temperature and heated air taken from the primary air supply piping for tunnel 2 are mixed together and are available at either test section for a variety of experimental purposes. Electric strip heaters along the auxiliary air flow piping maintain constant temperature conditions on this piping. Flow rates up to $2.5 \mathrm{pps}$ $(1.13 \mathrm{~kg} / \mathrm{sec})$ at temperatures up to $500^{\circ} \mathrm{F}$ $(533 \mathrm{~K})$ are available through this auxiliary system.

Both tunnels are also equipped with a particle spray system upstream of the test section. A schematic of this system is shown in Fig. 3. Particles immersed in a carrier liquid of water or ethyl alcohol are injected into the inlet air supply through an air-atomizing nozzle. Evaporation of the carrier liquid yields an air supply containing a precise particle size distribution. This system is used to seed the inlet supply air with spherical particles of known-size for laser anemometry experiments.

\section{$\underline{\text { Exhaust System Description }}$}

A vacuum exhaust of 26 in. of mercury $(\sim 1.5 \mathrm{psia}, \sim 10 \mathrm{kPa})$ is provided to both tunnels by the NASA Lewis central exhaust system. Each tunnel is double isolated from the low-pressure system by a set of butterfly valves, one remotely operated from the facility control room and one manually operated from within the test cell. For safety reasons and to avoid overloading the exhaust piping, the remotely operated valve on tunnels 1 and 2 cannot simultaneously be in an open position. 
The auxiliary exhaust piping system which is available at either tunnel test section can utilize the altitude exhaust system or can vent directly to the atmosphere outside the building. Uses of this subsystem include test section crossflow for actively cooled fin heat transfer studies, air injection or transpiration, and active supersonic boundary layer bleed.

\section{Safety Systems Description}

Several safety systems are present in the Engine Components Instrumentation Development Facility to protect personnel as well as critical hardware. Many of these features are required to maintain an in-cell personnel capability for the majority of operating conditions. The primary safety concerns of operating the facility are

(1) Laser radiation hazards

(2) Fire due to the use of high-voltage electricity or volatile seed particle carrier liquids

(3) Personnel injury due to the failure of a glass wind tunnel wall

Laser radiation hazards are minimized by the use of door interlocks and a beam shutter hardwired into the laser power circuitry. All test cell doors must be closed in order for power to be available to the laser. The laser operator may override this feature by using a keyswitch and pushbutton to activate a 15-sec delay to enter and exit the facility without interrupting the laser power. A beam shutter is also used in conjunction with the power safety circuitry. Since stray, misaligned laser beams aimed at tunnel 1 could potentially pass out of the test cell when the main doorway is opened with the override activated, a beam shutter automatically closes when the door is opened to avoid this potentially hazardous situation.

The threat of fire in the facility is minimized by the use of several devices. Three combustible gas detectors and two smoke detectors are located in the facility near seed particle spray points and potential ignition sources. These detectors continually monitor the flammability conditions at criti- cal locations within the facility. An infrared flame detector and a burn wire in the plenum of tunnel 2 also monitor facility conditions. Should any of these systems indicate a dangerous condition, the following series of safety events is initiated:

(1) The LFA particle seeding system is turned off.

(2) The electrical heaters are deenergized.

(3) Supply air and exhaust valves remain in the last position.

(4) The roof vent fan is energized.

(5) The evacuation horn and lights are energized.

Personnel injury due to the failure of a glass wind tunnel wall is minimized with two independent systems. Primarily, overpressurization of the tunnel 2 plenum and test section is guarded against by a redundant burst disk and pressure relief valve, both of which can be set at the maximum permissible operating pressure of the current test section. Second, injury of personnel due to glass failure is minimized by reinforced barricades placed between the tunnel wall and personnel.

\section{Controls and Data Systems Description}

Facility controls and health monitoring systems are located in a control room adjacent to the facility. The operator's panel and associated equipment are shown in Fig. 4. All facility equipment, with the exception of the manual exhaust valves, can be operated from this area. The inlet pressure to tunnel 2 is controlled by an electrically actuated ball valve. This valve can be stopped in any position along its travel to create the required pressure drop, providing the facility with inlet pressures ranging from 2 to 55 psia (14 to $380 \mathrm{kPa}$ ). Similarly, the exhaust valves can also be set at any position to create the necessary downstream pressure. The inlet temperature to tunnel 2 is controlled and maintained with two separate heating systems. The inlet piping and plenum are wrapped with electric heater strips which maintain the wall temperatures in 
equilibrium with the inlet air temperature. These strips are divided into four zones which can be individually controlled either in an ON/OFF or a proportional control mode. The inlet air itself is heated by two $300-\mathrm{kW}$ electric immersion heaters. Each heater is individually controlled in either an ON/OFF, proportional, or proportional-integraldifferential (PID) control mode. The set-point temperatures of all the heater controllers is set by the facility operator. The facility health monitoring is accomplished by using a datalogger, which records and displays all pertinent temperatures, pressures, and velocities. A touch screen allows the facility operator to select one of three health monitoring programs depending on the type of test run.

Experimental research data are collected and reduced on a minicomputer located in the test cell. To provide an efficient environment for debugging and checking out experimental equipment, all data acquisition components related to the experiment are located in the test cell. A precision electronic barometer, a high-accuracy, 64-channel, pressurescanning system and a 32-channel thermocouple system are interfaced with the computer to provide online control, calculations, and data reduction.

\section{$\underline{\text { Test Section Description }}$}

A modular test section design is incorporated in both of the wind tunnels in this facility. Each module is $16 \mathrm{in} .(0.4 \mathrm{~m})$ long and has a maximum flowpath cross section of 6 by 6 in. ( 0.15 by $0.15 \mathrm{~m}$ ). Tunnel 1 can be assembled with two to three modules for an overall length of 32 to 48 in. ( 0.8 to $1.2 \mathrm{~m})$. All modules are designed to be interchangeable and can be modified to specific requirements for specialized tests. Tunnel 2 requires three modules for an overall length of $48 \mathrm{in}$. $(1.2 \mathrm{~m})$. Inserts can be designed, fabricated, and installed in the channel to create specific flowpath geometries required for various experiments.

Two unique test sections are currently in use and a third is in the design phase. A subsonic/ supersonic test section with single-wall optical access is used to run tests on an open-beam LFA system. Figure 5 is a photograph of this test section installed in tunnel 1 . The throat area for this test section is 1 in. $^{2}\left(10^{-3} \mathrm{~m}^{2}\right)$. In addition to a straight-wall subsonic channel, discrete supersonic nozzle blocks with Mach numbers of 1.5, 1.7, and 2.0 available for this test system. Because of the small size of this flowpath and the relative importance of viscous effects, the nozzle blocks were extensively modified and redesigned using experimental results to produce acceptable flow quality. The axial static pressure distribution along the tunnel floor centerline is used to determine the flow velocity within the test section.

A second test section used in this facility is a heat flux sensor calibration module. A sketch of this test section module and a photograph of the instrumented heat flux gauge are shown in Fig. 6 . In this module, heated subsonic primary flow travels through a rectangular channel in the primary duct. A heat transfer fin with ambienttemperature cooling flow is mounted in the center of this channel. A unique plug-type heat flux gauge is machined into the center of this fin. The performance of this heat transfer fin is determined by detailed pressure, temperature, and flow measurements of both the primary and crossflow airstreams. The data from the heat flux gauge are then correlated to the heat transfer performance of the fin. This experiment can also be run conversely where ambient-temperature air is the primary flow and heated air flows through the fin.

A third test section for this facility is currently being designed. The objective of this module will be to study the dynamics and condensation effects of LFA seed particles in complex supersonic flows dominated by strong shock waves. The test module is $32 \mathrm{in} .(0.8 \mathrm{~m})$ long (double the length of the existing module), with dual-wall optical access which allows schlieren system verification of the shock wave structure. The design Mach number is 2.5. A mechanical system is used to locate a shock wave pattern with uniform downstream flow anywhere within the Mach-2.5 region of the nozzle. 
TABLE 1.-FACILITY AERODYNAMIC CAPABILITIES

[Low-pressure vacuum exhaust (for both tunnels and auxiliary piping),

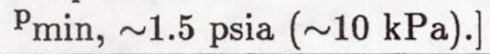

\begin{tabular}{|c|c|c|c|}
\hline \multirow[t]{2}{*}{ Capability } & \multicolumn{2}{|c|}{ Tunnel } & \multirow{2}{*}{$\begin{array}{l}\text { Auxiliary } \\
\text { piping }\end{array}$} \\
\hline & 1 & 2 & \\
\hline $\begin{array}{l}\text { Maximum inlet pressure, } \\
\text { psia }(\mathrm{kPa})\end{array}$ & Ambient & 55 psia $(380)$ & 55 psia $(380)$ \\
\hline $\begin{array}{l}\text { Maximum inlet } \\
\text { temperature, }{ }^{\circ} \mathrm{F}(\mathrm{K})\end{array}$ & Ambient & $500(533)$ & $500(533)$ \\
\hline Flow rate, $\mathrm{pps}(\mathrm{kg} / \mathrm{sec})$ & $5(2.3)$ & $10(4.6)$ & $2.5(1.13)$ \\
\hline Filtration, $\mu$ & None & 1.5 & 10 \\
\hline Maximum Mach number & 1.7 & 3.0 & $\mathrm{~N} / \mathrm{A}$ \\
\hline LFA particle seeding & Yes & Yes & $\mathbf{N} / \mathbf{A}$ \\
\hline
\end{tabular}




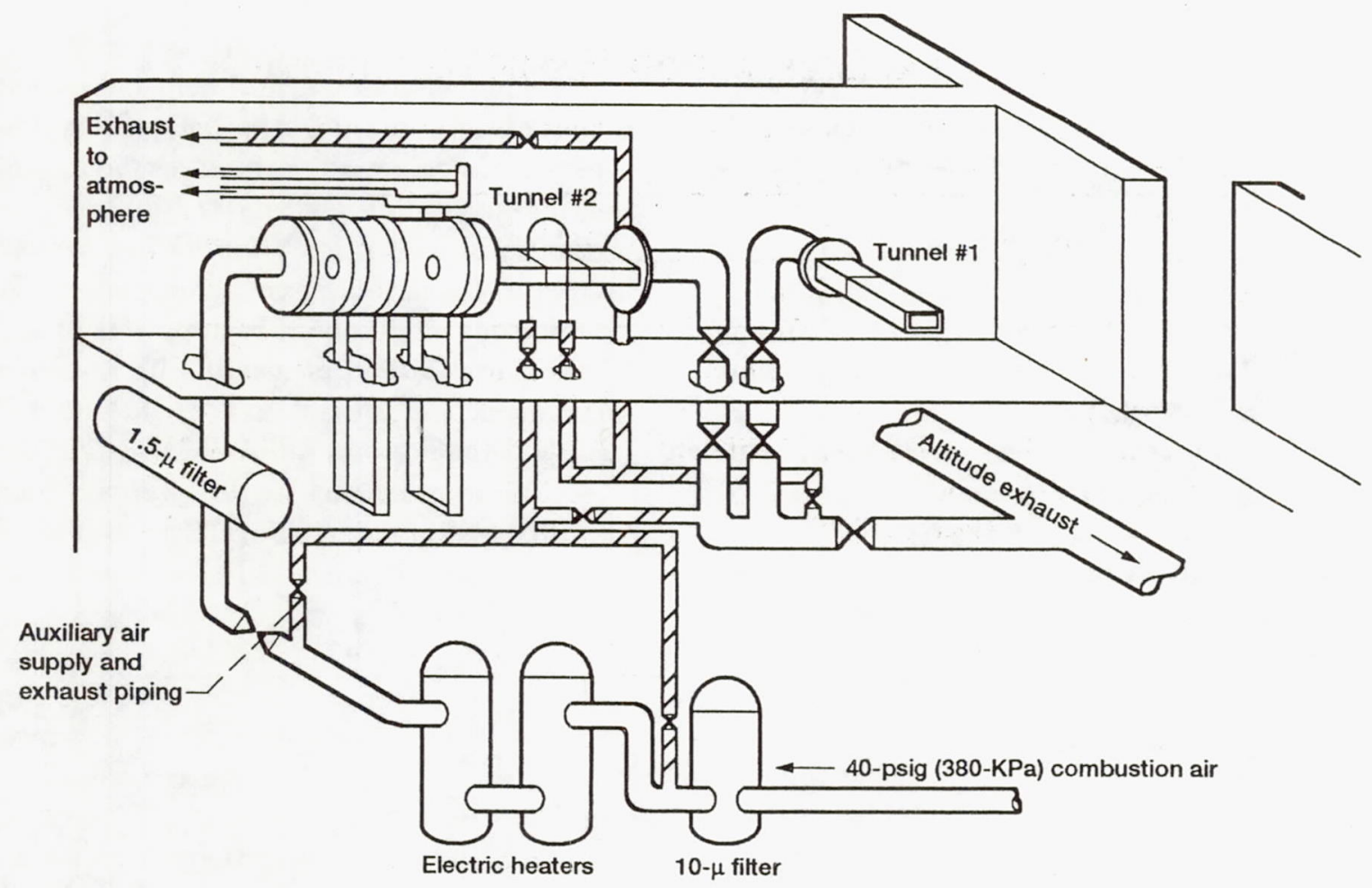

Fig. 1. Isometric view of facility.

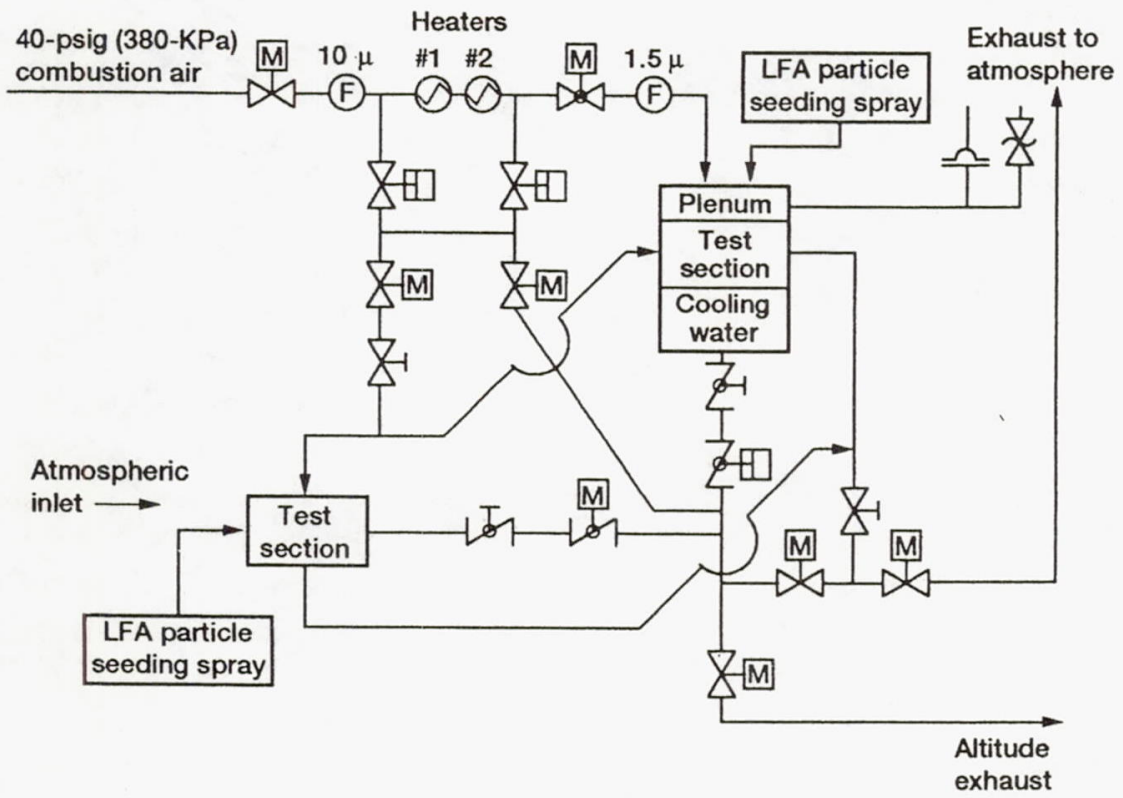

Fig. 2. SE-1 air supply and exhaust system. 


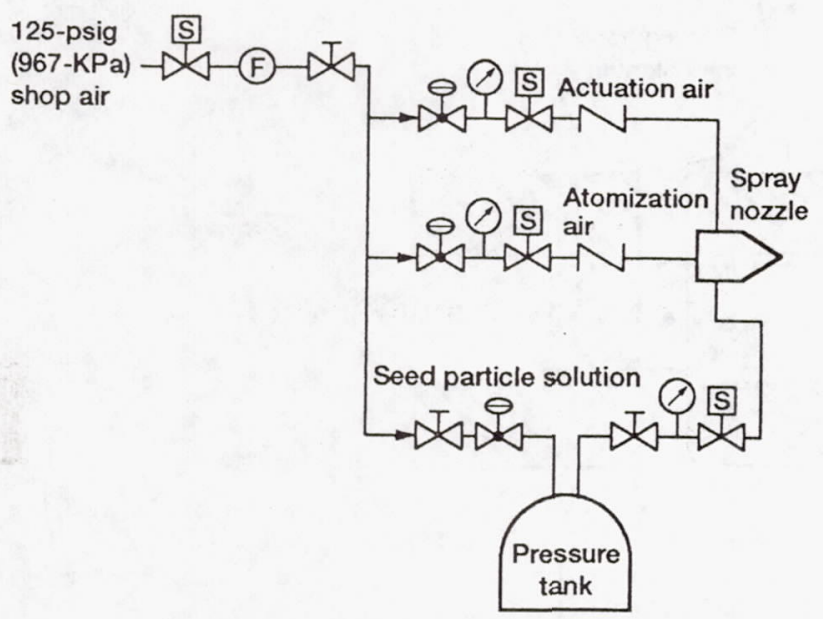

Fig. 3. LFA particle seeding system.
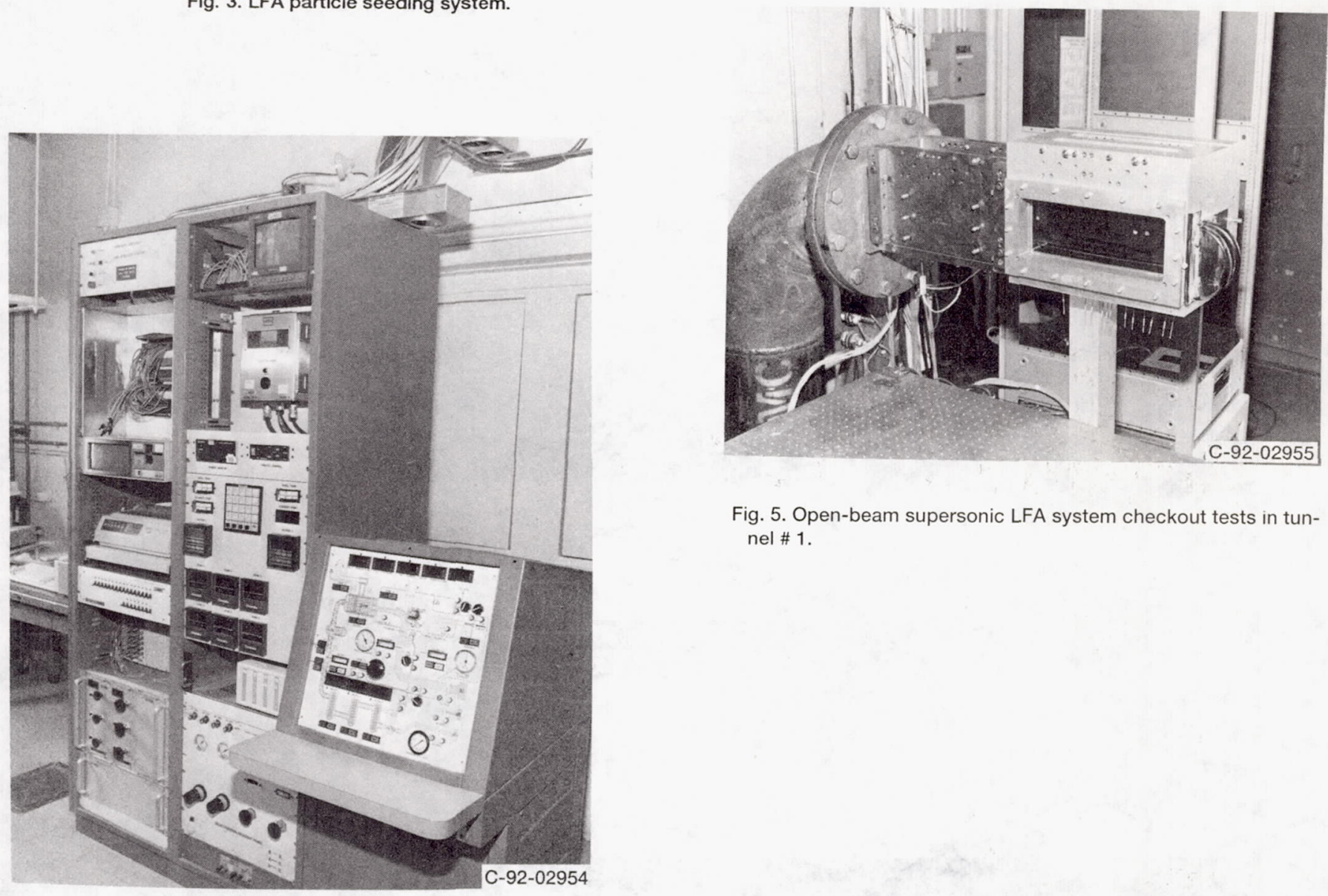

Fig. 5. Open-beam supersonic LFA system checkout tests in tunnel \# 1.

Fig. 4. Control room. 

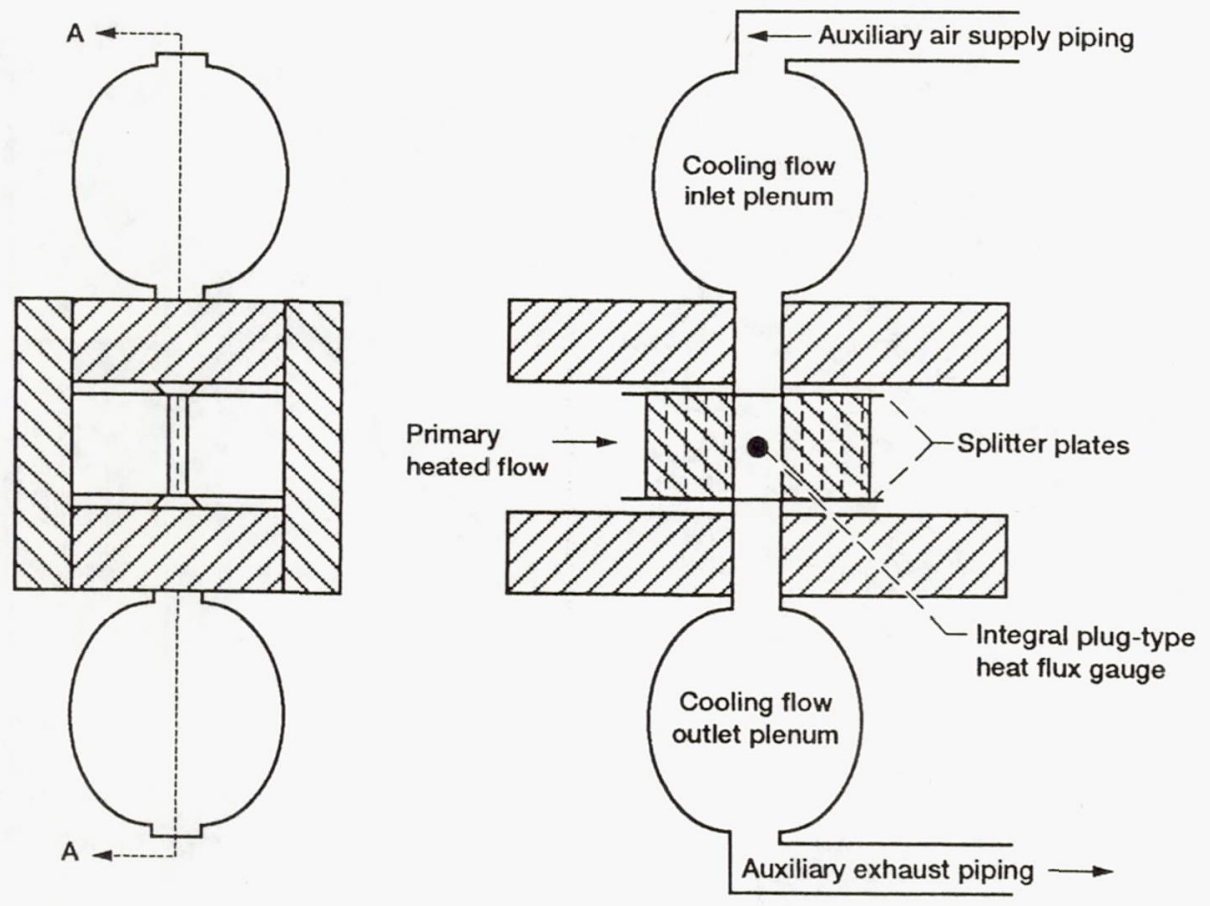

(a) Heat flux gauge calibration module.

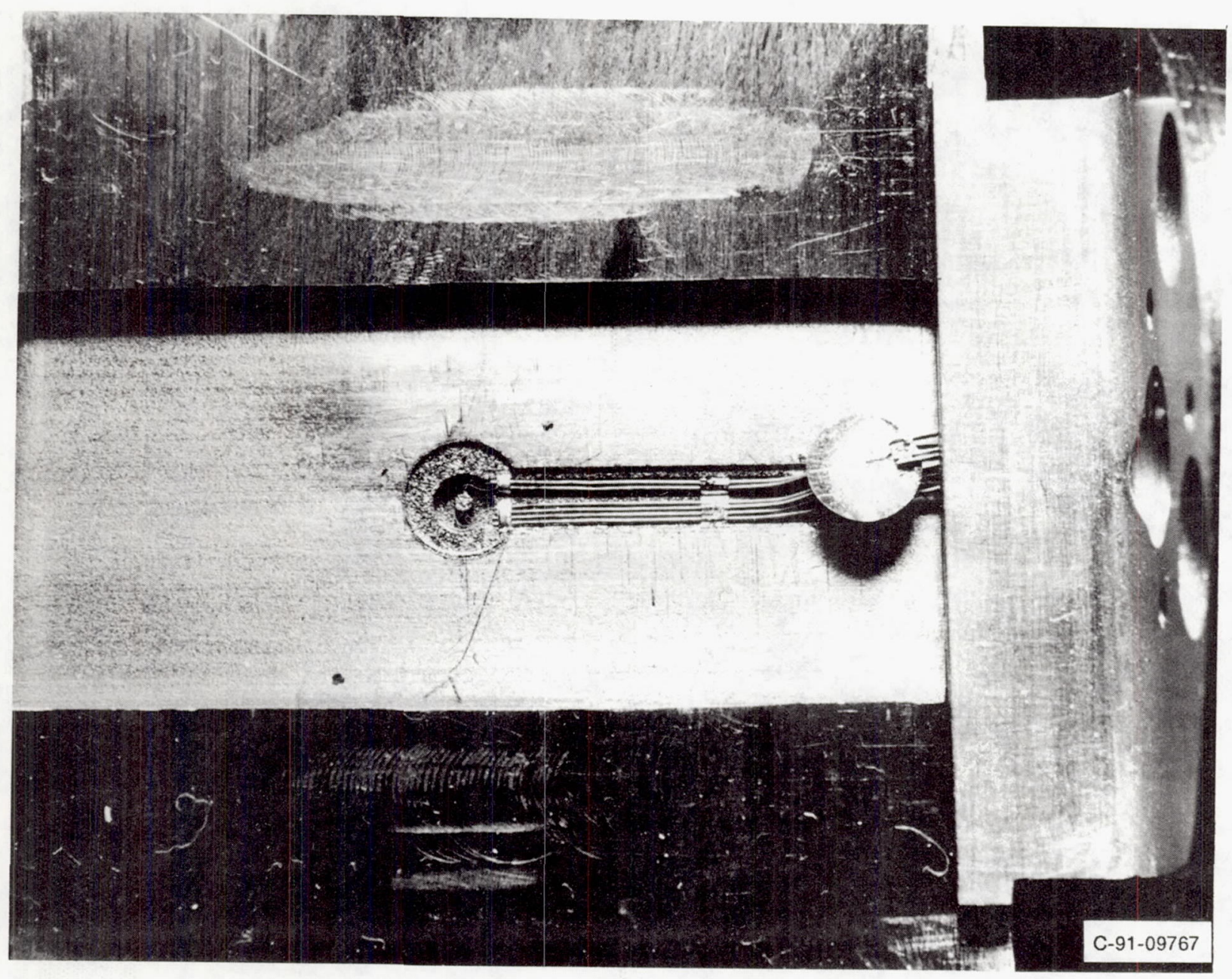

(b) Instrumented heat flux gauge.

Fig. 6. Heat flux calibration test section in tunnel \#2. 

Public reporting burden for this collection of information is estimated to average 1 hour per response, including the time for reviewing instructions, searching existing data sources, gathering and maintaining the data needed, and completing and reviewing the collection of information. Send comments regarding this burden estimate or any other aspect of this collection of information, including suggestions for reducing this burden, to Washington Headquarters Services, Directorate for information Operations and Reports, 1215 Jefferson Davis Highway, Suite 1204, Arlington, VA 22202-4302, and to the Office of Management and Budget, Paperwork Reduction Project (0704-0188), Washington, DC 20503.

\begin{tabular}{|l|l|l|}
\hline 1. AGENCY USE ONLY (Leave blank) & 2. REPORT DATE & 3. REPORT TYPE AND DATES COVERED
\end{tabular}

\section{2}

4. TITLE AND SUBTITLE
Technical Memorandum

Engine Component Instrumentation Development Facility at NASA Lewis Research Center

\section{AUTHOR(S)}

Robert J. Bruckner, Alvin E. Buggele, and Jan Lepicovsky

\section{PERFORMING ORGANIZATION NAME(S) AND ADDRESS(ES)}

National Aeronautics and Space Administration

Lewis Research Center

Cleveland, Ohio 44135-3191

5. FUNDING NUMBERS

$$
\text { WU-505-62-84 }
$$

8. PERFORMING ORGANIZATION REPORT NUMBER

$$
\text { E-6999 }
$$

\section{SPONSORING/MONITORING AGENCY NAMES(S) AND ADDRESS(ES)}

10. SPONSORING/MONITORING AGENCY REPORT NUMBER

National Aeronautics and Space Administration

Washington, D.C. 20546-0001

NASA TM-105644

AIAA-92-3995

\section{SUPPLEMENTARY NOTES}

Prepared for the 17th Aerospace Ground Testing Conference sponsored by the American Institute of Acronautics and Astronautics, Nashville, Tennessee, July 6-8, 1992. Robert J. Bruckner and Alvin E. Buggele, NASA Lewis Research Center; Jan Lepicovsky, Sverdrup Technology, Inc., Lewis Research Center Group, 2001 Aerospace Parkway, Brook Park, Ohio 44142. Responsible person, Robert J. Bruckner, (216) $433-6499$.

12a. DISTRIBUTION/AVAILABILITY STATEMENT

12b. DISTRIBUTION CODE

Unclassified - Unlimited

Subject Category 09

\section{ABSTRACT (Maximum 200 words)}

The Engine Components Instrumentation Development Facility at the NASA Lewis Research Center is a unique aeronautics facility dedicated to the development of innovative instrumentation for turbine engine component testing. Containing two separate wind tunnels, the facility is capable of simulating many flow conditions found in most turbine engine components. This facility's broad range of capabilities as well as its versatility provide an excellent location for the development of novel testing techniques. These capabilities thus allow a more efficient utilization of larger and more complex engine component test facilities.

14. SUBJECT TERMS

Supersonic wind tunnels; Subsonic wind tunnels; Turbine instruments; Laser doppler velocimeters

15. NUMBER OF PAGES

10

16. PRICE CODE

$\mathrm{AO3}$

17. SECURITY CLASSIFICATION OF REPORT

Unclassified
18. SECURITY CLASSIFICATION OF THIS PAGE Unclassified
19. SECURITY CLASSIFICATION OF ABSTRACT

Unclassified 

National Aeronautics and

Space Administration

Lewis Research Center

Cleveland, Ohio 44135

Official Business

Penalty for Private Use $\mathbf{\$ 3 0 0}$
FOURTH CLASS MAIL

\section{ADDRESS CORRECTION REQUESTED}

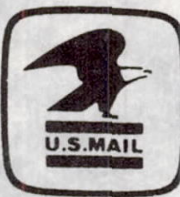

Postage and Fees Paid

Natıonal Aeronautics and Space Administratıon NASA 451 